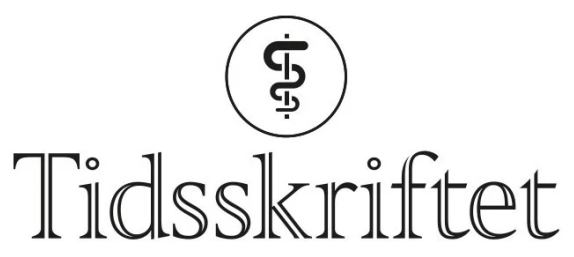

DEN NORSKE LEGEFORENING

\title{
Rettelse: Hørselskontroll er dårlig støyvern
}

RETTELSE

\section{ERLEND HASSEL}

Tidsskr Nor Legeforen 2021; 141: 1171-3.

I Tidsskriftet nr. 12/2021, s. 1173 skal det stå: Dette vil kunne bidra til å dra fokus vekk fra der hvor risikoen er størst og føre til feil prioritering av tiltak.

Vi beklager feilen, den er rettet på nett.

Publisert: 26. oktober 2021. Tidsskr Nor Legeforen. DOI:10.4045/tidsskr.21.0641

(C) Tidsskrift for Den norske legeforening 2023. Lastet ned fra tidsskriftet.no 26. april 2023. 